\title{
Construction Trajectory of Bekakak Tradition in Gamping: Analytical Study of Peirce Semiotics
}

\author{
Desiana Muryasari ${ }^{1, *}$ Trie Hartiti Retnowati ${ }^{2, * *}$
}

\author{
${ }^{1}$ Arts Education Graduate Program, Yogyakarta State University, Depok 55281, Yogyakarta, Indonesia \\ ${ }^{2}$ Department of Fine Arts Education, Yogyakarta State University, Depok 55281, Yogyakarta, Indonesia \\ *Corresponding author. Email: dmuryasari@gmail.com \\ ***orresponding author.Email: trihartiti54@gmail.com
}

\begin{abstract}
The tradition of the Bekakak doll couples in Gamping, Yogyakarta, is a ceremony scheduled for each year in the Sapar Islamic-Javanese calendar in which the month of Sapar means October in 2019. This ceremony performs the slaughter of a couple of Bekakak brides made of glutinous rice flour as a form of offerings to repel reinforcements. This study focuses on the Bekakak couples from their historical perspective, philosophy, and semiotic characteristics. The method used was descriptive qualitative with Peirce's semiotic analysis. Data were obtained through observation, interview, and documentation of photos, videos and recordings and analyzed by means of the Peirce semiotic approach by reviewing the meaning of the sign (icon, index, and symbols), object, and "interpretant" (the meaning of the sign). The results of the study reveal that the sign on the shape and color of the Bekakak brides describes the followings. First, the construction of the Bekakak couples forms its roots in the visual form of human brides that is fully equipped with fashion and accessory styles of Yogyakarta Paes Ageng. Second, the construction of the Bekakak has experienced significant changes, especially in the dimensions of form, meaning, and function. Third, along with the development of the industry 4.0, Bekakak tradition experienced commodification through creative industries now being aggressively discussed by the Indonesian government.
\end{abstract}

Keywords: bride, Bekakak, tradition, semiotics

\section{INTRODUCTION}

Indonesia is a country rich in culture. Every region in Indonesia has various forms of traditional art. The diversity of traditional arts is part of local culture that grows and develops along with the times. Traditional art in general cannot be known with certainty when and who is the creator. Culture that is inherent in society and has been hereditary for a long time, will be increasingly conceptualized in people's lives so that it becomes a belief in matters relating to a belief that is difficult to dispel. According to Soemardjan and Soemardi, culture is a means of creation, taste, and creativity of the community [1]. The values of local wisdom that still exist are usually still maintained by people who still have a strong level of trust. The belief that is still inherited in the community is also caused by the culture that is usually universal, so that the culture has been attached to the community and has become an essential matter in its life. From this, then there is an assumption that humans are creatures of culture as well as creators of culture. Culture itself is formed from ideas, symbols, and values as a result of the work of human action.
Koentjaraningrat argues that "kebudayaan" comes from Sanskrit buddhayah is the plural of words buddhi which means mind or reason, so according to him culture can be interpreted as matters related to mind and reason [2]. Regarding the preservation of local culture in this case the Saparan Bekakak tradition, Jacobus Ranjabar argues that the preservation of the old national norms (local culture) is to preserve the values of art and culture, traditional values by developing embodiments that are dynamic, flexible and selective, as well as adjusting to situations and conditions which is always changing and developing [3].

One unique culture and art that is still preserved is the Bekakak tradition in Ambarketawang Village, Gamping, Yogyakarta. It is important to remember that D.I. Yogyakarta is one of the alternative roads in the education, panorama, art and culinary tourism corridors. The Bekakak tradition is a tradition that is handed down for generations annually on Fridays between the 10th-20th in the Sapar month (in the Javanese calendar). Ambarketawang Village is one of five villages within the Gamping District of Yogyakarta. Bekakak Ceremony is a traditional ceremony organized by the Ambarketawang community, Gamping District by slaughtering a pair of Bekakak (a pair of 
wedding dolls made from glutinous rice flour and Javanese rice, red Javanese sugar syrup).

The purpose of the tradition of the slaughtering of Bekakak brides is as a reinforcement for the people around Mount Gamping to avoid disaster because the majority of Gunung Gamping residents are limestone miners. Since the ceremony was held for the first time, it was believed by the community that Mount Gamping had taken no more casualties because every year a pair of Bekakak brides had been sacrificed. It is undeniable that this traditional ceremony was initially influenced by Hindu culture considering Hindu culture first entered Indonesia and the Javanese culture itself in Java.

The Bekakak tradition is classic because it has existed since the time of Sri Sultan Hamengku Buwono I in 1755. Before performing the ritual, Gunung Gamping often takes its toll, namely the surrounding community, which is the majority of limestone collectors, as well as to commemorate the loyalty of one of Sri Sultan Hamengku Buwono I's favorite servants named Kyai Wirasuta and his wife Nyai Wirasuta. The history of this tradition began when the construction of the Yogyakarta Palace was underway. Sri Sultan Hamengku Buwono I lived in a boarding house in Ambarketawang with the servants of the palace, one of the palace servants who was loved by Sri Sultan Hamengku Buwono I namely Kyai Wirasuta. After the construction of the palace was completed, Sri Sultan Hamengku Buwono I along with the courtiers wanted to return to the palace, but Kyai Wirasuta and his wife chose to stay in the cave which was none other than Sri Sultan Hamengku Buwono I's guesthouse. The slaughter of Bekakak doll takes place in two different places, Mount Ambarketawang located in the hamlet of Gamping Kidul and Gunung Gamping. According to the story that developed in the community, one day there was a landslide because the spirits on Gunung Gamping did not like if there were humans living in caves.

This pair of Bekakak brides are made of glutinous rice flour was made resembling humans and dressed up like a bride complete with offerings placed on a coffin decorated with various kinds of flowers and leaves. A pair of Bekakak brides contains Javanese sugar syrup or juruh which is interpreted as blood, so that when the bridegroom is slaughtered, it is as if bleeding. Since the ceremony was held for the first time, it was believed by the community that Mount Gamping had taken no more casualties because every year a pair of Bekakak brides had been sacrificed. It is undeniable that this traditional ceremony was initially influenced by Hindu culture considering Hindu culture first entered Indonesia and kejawen culture itself in Java.

Currently Bekakak experienced a shift in function that was originally used as a sacred traditional ceremony, now turned into a profane tradition to support tourism and entertainment. Bekakak bridal tradition has become the annual agenda in Gamping as a form of effort to preserve tradition as well as a special attraction for tourists. This happened along with the development of the times considering that at this time the world entered the era of the Industrial Revolution 4.0, rapid technological advances also influenced the development of traditions, one of which was Bekakak. Tjandrawinata explained that new technologies and approaches in the Industrial Revolution 4.0 combining physical, digital and biological world will fundamentally change the patterns of life and human interaction [4]. Thus, it is hoped that technological progress can have a positive impact on the Bekakak tradition.

Based on reviews in the background, the purpose of the study are as follows (1) Review the meaning of sign from Peirce's semiotics in the Bekakak tradition in Gamping and describe the development of Bekakak form construction (2) Analyze visual construction of form, meaning and function (3) Describe the development of Bekakak in the Industrial Revolution era 4.0.

\section{RESEARCH METHOD}

This study uses a qualitative approach because the data used are qualitative data. Andi Prastowo explained that in qualitative research, the data collected were in the form of descriptive data, for example personal documents, field notes, respondent actions, and documents [5].

This research focuses on the meaning of the sign behind the Bekakak tradition in Ambarketawang Village, Gamping D.I. Yogyakarta, describing the development of the Bekakak form construction and visual analysis of forms, meanings and functions. The study was conducted in August 2019. Data collected by in-depth interviews, participatory observation and documentation. The available data were analyzed with Peirce's semiotic theory, which is a trichotomy theory consisting of representment, objects and interpretants.

Semiotics is the study of signs. The emergence of semiotics offers an opportunity to see things from another perspective. According to Sobur, semiotics is a science or method of analysis to study signs [6]. Peirce was a philosopher and logician who was a major figure in the history of semiotics. He is also known as the modern inventor of the sign [7].

Peirce defines a sign with something that refers to someone over something in some way and capacity. In reading these signs, Peirce uses the concept of triadic. The first category is called representments, then there are objects, and the third part is interpretants. The basis of these three triadic concepts is the existence of representment and then towards the object, then the interpretant is then obtained [8]. In Bekakak there are certainly also the Peirce semiotic triadic concept as follows: 


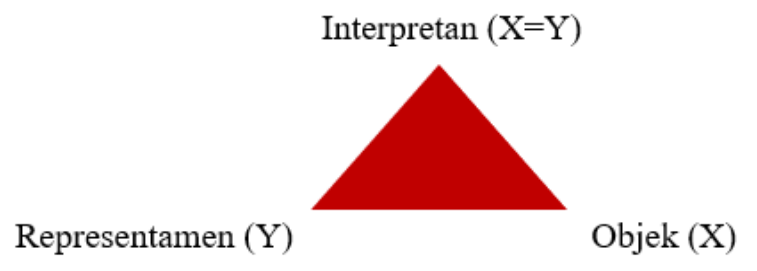

Figure 1 The Peirce Semiotics Triadic Concept

The concept of triadic is the process of semiosis (triadic process), and the sustainable relationship, that is, the interpretant will develop into a representative and so on. But it needs to be clarified, that the interpretant is what is produced by the sign and in the quasi-mind is the interpreter, but he can also be understood as a representative. So that there will be a process of development in an endless interpretation in accordance with the development of the existing period [9].

\section{RESULTS AND DISCUSSION}

\subsection{The Meaning of the Bekakak Signs and the Development of Form Construction}

Based on Peirce's semiotic triadic above, the following results are obtained:

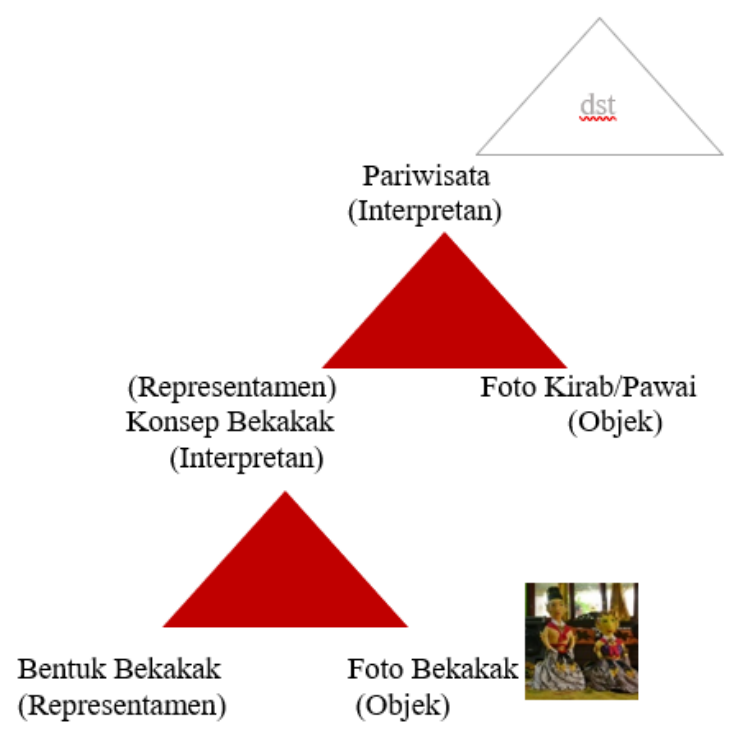

Figure 2 Bekakak in Peirce Semiotics

First the representment is something that was first captured by the five human senses, shown by the constructive form of the Bekakak. Second, Bekakak's photo or picture as an object and Bekakak as an interpretive concept of the form of a pair of brides who will be used as offerings on Mt. Gamping so that the surrounding community will be protected from disaster. Furthermore, the interpretation of Bekakak as a sacrificial object can develop into a representative with a photo of the parade / parade as its object so that the interpretation of the Bekakak tradition emerges as tourism and so on.

A pair of Bekakak brides who will be used as offerings on Mount Gamping are formed close to naturalists like humans, although not yet perfect when viewed from proportions. The form of the Bekakak bride consists of the head, body, hands and feet. Being made up and clad in clothing like a real bride, that is Paes Ageng Basahan dress Paes Ageng is a bridal makeup that has the highest position and has social and cultural philosophy. The makeup and fashion in Paes Ageng is not only concerned with aesthetic elements but also is rich in philosophy and hope.

The start of the Bekakak bride was only formed simply consisting of 3 parts, namely the head, body and hands wrapped only with tulak cloth as a symbol of offerings. The community believes that the spirits of the guardians of the cave of Mount Gamping can be fooled by the Bekakak bride. One of the photo collections currently kept neatly by Mr. Bambang Cahyono is the results of the 1974 Bekakak documentation where it is clear that a pair of Bekakak brides in terms of their shape are still relatively simple and clad in tulak cloth. Here are photos of the appearance of the 1974 Bekakak form:

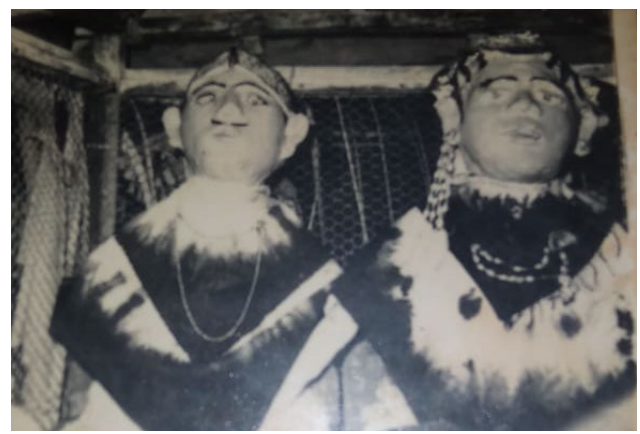

Figure 3 Bekakak in 1974

Initially, the Bekakak doll was only wrapped using a classic Javanese motif cloth, namely the bangun tulak fabric (bango-tulak) as a form of offering, which is a fabric with only two colours, dark blue with white in the middle. Bangun tulak fabric symbolizes repellent, blue is the symbol of the earth and white is the symbol of the sky so that everything will return to the ruler of the universe, God Almighty. Makeup on Bekakak's bride is also not as complete as today. 


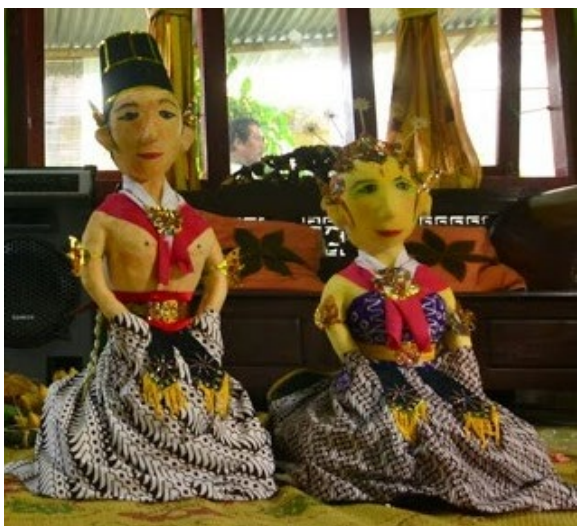

Figure 4 a Pair of Bekakak

The shape of the Bekakak bride is made to imitate/resemble the shape of a human bride made of glutinous rice flour which contains juruh (brown sugar syrup). The glutinous rice flour was given a brownish yellow color from turmeric so that the color of the Bekakak bride was similar to the color of Javanese skin. As the times have evolved, Bekakak's form has also developed, which has increasingly accentuated its aesthetic side through the creative hands of its makers.

\subsection{Visual Construction Analysis of Form, Meaning and Function}

The development of the Bekakak form every year is becoming more perfect and more complete in terms of the shape of the Bekakak itself and the accessories used. Here are the results of an analysis of the shape of the Bekakak accessories. The following is an illustration of the Bekakak bride and the results of the analysis of the form, meaning and function of the Bekakak accessory:

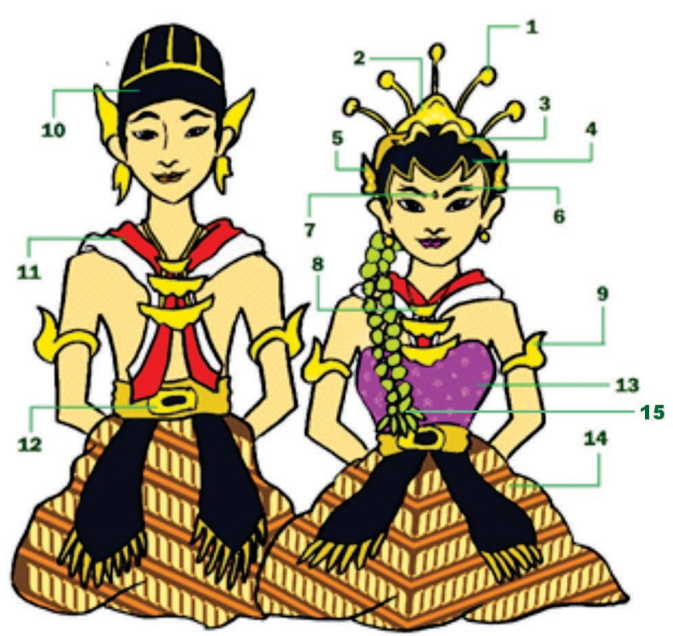

Figure 5 Illustration of A Couple of Bekakak and Their Descriptions
1. Cunduk Mentul is a decoration above the towering head, shaped like the sun made of odd-numbered metals. The shape that resembles the sun symbolizes the hope that the bride and groom's wedding will always be illuminated by the sun, the giver of life. The number of cunduk mentul usually consists of $1,3,5,7$, or 9 circles with different meanings. Cunduk mentul of which one is a symbol of the oneness of God. A total of three as a symbol of Trimurti. Number 5 is a symbol of Islamic harmony. Seven is a symbol of help because seven in Javanese is "Pitu" which is believed to be a symbol "Pitulungan" (help). The highest number is 9, as a symbol of Walisongo.

2. Mountains Sariayu is a triangle shaped decoration resembles the shape of a mountain as a symbol of greatness. The mountain is believed by the people of Java as a sacred and holy place.

3. Two Centhung is a pair of comb accessories with gemstone ornaments embedded in the left and right of the bride's head. The shape resembles the shape of a gate or entrance, as a symbol that the woman is ready to enter the marriage gate.

4. Shape paes, panunggul, pinchers, dropper (decoration on the forehead with a gold border / prada). Panunggul is a decoration in the form of a mountain or betel leaf and there are 3 points as a symbol of Trimurti in the Hindu religious concept, namely Shiva, Brahma and Vishnu. The top penunggul shaped betel leaf facing down is a sign that as humans we must obey and submit to God Almighty. In the Bekakak bride, black colouring uses jelaga which is mixed with coconut oil.

5. Sumping Sekar Sritaman is decoration placed on the ear. Currently the sumping used by brides is made of metal plates. But in the beginning, sumping used by the descendants of the king is made of papaya leaves. It is because, papaya leaves taste bitter. It indicates that the household must be prepared to feel a variety of bitterness.

6. Eyebrow shaped menjangan ranggah is a form of stilation of deer antlers which describes beauty and as hope that a wife must be agile and nimble.

7. Citak for Paes Ageng Kebesaran is made from betel leaves in the form of rhombus which has a central symbolic meaning of all human creativity. Citak is a symbol that women must always focus on the future.

8. Necklace Sungsun is a three-tiered necklace that is a symbol of the three phases of human life that must be passed through namely birth, marriage and death.

9. Kelat bahu is a decoration pinned on the bride's shoulder. This Kelat is in the form of a dragon whose head and tail are interlocked, it symbolizes the merging of a pattern of taste and a mindset. The meaning contained in it is a hope to gain sustenance and strength in living life. Dragon are animals that are believed to have great strength. 
10. The groom uses kuluk as a head covering, which is a symbol of the greatness of a king. A man must be able to be a good leader and protector.

11. Shawl/cloth found on the body of the bride Bekakak, is in red and white images. Now every year the color of the shawl/cloth changes to make it more varied. The green-white shawl/cloth symbolizes fertility while the red and white colours adopt the colours of the NKRI flag as a symbol of Indonesian unity.

12. Selepe is a belt that has meaning to remind people to be always close to the creator and must be strong in faith.

13. Fabric Cinde is a fabric with a variety of geometric decorative motifs resembling plants adapted from Patola fabric in India and only used for ceremonies and as a symbol of fertility and repelling reinforcements.

14. Clothes Dodot or hem is a symbol of human decency and represent greatness. Fabric dodot or hem is mostly patterned as cement which means "semi" (fertility). In Bekakak's bride, the clothes used are batik, a traditional Javanese cloth.

15. Gelung Bokor is a form of hair makeup with a model sanggul. Hair is bent and shaped gelung tekuk / ukel bokor has a meaning that was immature into an adult and already has a basis (golig gilig) towards the direction of perfection. In wayang, it is described as Bratasena meguru marang Dewa Ruci. What is meant is that the nature of the human being is completely round and then becomes perfect and is kept well for as long as life so that until the end of life it leaves a fragrant name. Then sanggul bokor is closed with jasmine strands [10].

\subsection{Bekakak Era of Industrial Revolution 4.0}

One of the characteristics of the Industrial Revolution 4.0 is the application of Artificial Intelligence [4]. This is also in accordance with what Satya revealed, that the 4.0 Industrial Revolution is a digitally connected industrial process that includes various types of technology, ranging from 3D printing to robotics which is believed to be able to increase productivity [11]. The 4.0 Industrial Revolution, which is full of super-fast, all-digital and automated technology, has brought significant changes in various fields of life, one of which is the culture and tradition in Indonesia. Javanese tradition has an abundance of meaning that is able to give the message that every human being has a role in a life. It is an obligation to continue to maintain the cultural traditions of one's own country in the midst of the rapid development of an increasingly modern world. It is not only science and technology that is developing but local traditions are also developing. This can be seen through the form and make-up of the Bekakak bride which is increasingly complete to resemble a real human bride.

Bekakak bride tradition experienced a shift in function that was originally used as a sacred ceremonial tradition, so that now it is a profane tradition in order to support tourism. Bekakak bridal tradition has become an annual event in Gamping, Sleman. The Bekakak ceremony has experienced very significant developments, both in terms of personnel and the transportation used. In terms of personnel, in the beginning, this traditional ceremony was attended by the palace servants and also the families of the Yogyakarta Palace and the community around Ambarketawang Village. Whereas the general public can only be their audience. But now that does not happen. Because this traditional ceremony has become a national traditional ceremony. The community still welcomes this tradition, the community's enthusiasm can be seen from the increasing number of participants who take part in the parade, ranging from drum bands, dances and various kinds of Ogoh-ogoh. Now the Bekakak Ceremony is just a tradition that must be preserved and used as a tourist attraction. Moreover, this event has entered the international tourism calendar, especially for the Yogyakarta region.

The existence of the Industrial Revolution 4.0 has a big influence on the development of tradition and the arts, for example the YouTube application. Through this application, the wider community outside the Special Region can watch a series of events on the Bride and Groom via Streaming without having to be physically present. In addition, similar applications can also be used as a forum to promote the Bekakak tradition as a tourist attraction. The Bekakak can be a magnet for domestic and foreign tourists, thus inviting traders to peddle their wares around the location of the Bekakak event. This is an advantage for society in the economy.

\section{CONCLUSION}

The tradition of the Bekakak bride which is held annually in Gamping, Yogyakarta is the ceremony of slaughtering a pair of Bekakak brides which was originally held as a form of offering reinforcements so that the community around Mount Gamping is protected from disasters. Bekakak's bride is made of glutinous rice flour which contains Juruh (brown sugar syrup) so that when the bride is slaughtered, the juruh is interpreted as blood. The Bekakak Bride is shaped like a human bride, decorated in such a way as complete with supporting accessories. The makeup and clothing worn by the Bekakak bride is the style of the Paes Ageng Yogyakarta which is rich in social and cultural philosophy through shapes and colours as a symbol of hope. 
The shape of the Bekakak bride which is now experiencing the commodification of the form of the old Bekakak bride, considering the technological advances so that people prioritize aesthetics and innovation. Now the Bekakak bride is not as a form of sacred ritual ceremony as before but has become a supporting tourism event. The annual agenda of the Bekakak bride further strengthens the sense of mutual cooperation of the local community and can also be a venue for channelling creativity through the Bekakak bridal innovation without losing the essence and aesthetics of the Bekakak itself. So that with the success of cultural tourism, the Bekakak is expected to develop the region, bring active community participation, the spirit of building the region towards improving people's welfare.

\section{REFERENCES}

[1] Simanjuntak, Posman. Berkenalan dengan Antropologi untuk SMU Kelas 3 [Get Acquainted with Anthropology for High School Grade 3]. Jakarta: Erlangga, 2003. p. 136.

[2] Koentjaraningrat, R. M. Kebudayaan, mentalitas dan pembangunan [Culture, mentality and development]. Gramedia, 1993.

[3] Ranjabar, Jacobus, and Risman F. Sikumbank. Sistem Sosial Budaya Indonesia: Suatu Pengantar [Indonesian Socio-Cultural System: An Introduction]. Alfabeta, 2006. p. 114.

[4] Tjandrawinata, Raymond R. "Industri 4.0: Revolusi industri abad ini dan pengaruhnya pada bidang kesehatan dan bioteknologi [Industry 4.0: The Industrial Revolution of this century and its influence in the fields of health and biotechnology]." Jurnal Medicinus 29.1 (2016). pp. 31-39.

[5] Prastowo, Andi. Metode Penelitian Kualitatif dalam Perspektif Rancangan Penelitian [Qualitative Research Methods in the Perspective of Research Designs]. Yogyakarta: Ar-Ruzz Media, 2011. p. 43.

[6] Sobur, Alex. Semiotika komunikasi [Communication semiotics]. Remaja Karya, 2017. p. 15.

[7] Noth, Winfried. Semiotik, Handbook of Semiotics (Advanced in Semiotics). Airlangga University, 2006. p. 39.

[8] Noth, Winfried. Semiotik, Handbook of Semiotics (Advanced in Semiotics). Airlangga University, 2006. p. 42
[9] Eco, Umberto. "Teori Semiotika, Signifikasi Komunikasi, Teori Kode Serta Teori ProduksiTanda [Theory of Semiotics, Communication Significance, Theory of Code and Theory of the Production-Sign]." Yogyakarta: Kreasi Wacana (2015). p. 99.

[10] Yosodipuro, Marmien Sardjono. Rias pengantin gaya Yogyakarta: dengan segala upacaranya [Yogyakarta-style bridal makeup: with all the ceremony]. Kanisius, 1996.

[11] Satya, Venti Eka. "Strategi Indonesia Menghadapi Industri 4.0 [Indonesia's Strategy in Facing Industry 4.0]." INFO Singkat 10.9 (2018). p. 20. URL: http://sdip.dpr.go.id/search/detail/category/Info $\% 2$ 0Singkat/id/816 